\title{
Improving the the Financial Stability of Agriculture under Conditions of Modernization of the Economy
}

\author{
Temirkhanova Mo'tabar Juraevna ${ }^{{ }^{*}}$, Fayzieva Umida Tairjanovna ${ }^{1}$, and \\ Abdullayev Khurshid Narzullayevich ${ }^{2}$
}

$1 \mathrm{PhD}$, Dotcent at the Tashkent State Economics University

2Researcher of TSLI

\begin{abstract}
In the article the state of financial sustainability of agriculture in the country and the prospects for improving the mechanisms for financing the industry are analyzed. Also discussing about production of agricultural products in the agricultural sector of the country by working in harmony with national traditions, creation of unique competitive products, reporting on the natural location of territories, exporting them at the level of products that are in great demand both in the domestic and foreign markets. The reweals the ways to ensure the financial stability of agriculture under conditions of modernization of the economy of the Republic of Uzbeklistan and its improving ways.
\end{abstract}

Corresponding author: Temirkhanova Mo’tabar Juraevna, Department International economy, At the branch FSBE HE “Russian university of economics behalf of G.V. Plekhanova “in Tashkent. Email: mutabarchik@mail.ru

Received: December: 21, 2019, Accepted: December: 29, 2019, Published: December: 31, 2019

Keywords: Modernization, Integration, Diversification, Innovation, Food Security, Agricultural Financing, Investment, Agricultural Policy

\section{Introduction}

Formation of a competitive innovative economy in the country, including sustainable development in the agricultural sector: ensuring food security and independence of the country, improving the living standards and quality of life of the rural population, the rational use of natural resources and environmental protection, is one of the priority areas of state economic policy.

Over the past period, radical structural changes have been occurred as a result of economic reforms in agriculture. In particular, a comprehensive legal framework has been created for economic reform; ownership is formed and the corresponding forms of economic management of agricultural production are created, optimal conditions are created for the functioning of farms and dekhan farms as a promising form of economic ownership in the industry; improved attitude to the ownership and use of land as the main production tool of agriculture; an independent agrarian policy has been developed and is being consistently implemented, which provides regular supply of the population with their own food products; market principles are effectively used in the production, processing, sale and servicing of products.

With the aim of organizing diversification of production, improving land and water relations, creating favorable conditions for agribusiness and the high value chain, supporting the development of cooperative 
Citation: Temirkhanova Mo'tabar Juraevna (2019) Improving the the Financial Stability of Agriculture under Conditions of Modernization of the Economy. Journal of Media \& Management. SRC/JMM-103. DOI: doi.org/10.47363/JMM/2019(1)103

relations, widespread introduction of market mechanisms, information and communication technologies in the industry, as well as the effective use of scientific achievements on October 23, 2019 The President of the Republic of Uzbekistan signed the Decree "On approval of the Strategy for the Development of Agriculture of the Republic of Uzbekistan for 20202030" [1].

The following areas were identified as priority areas for the implementation of the strategy:

1. Development and implementation of the state policy on food security, which provides for food safety and improving the diet, the production of food products in the required quantity.

2. Creating a favorable agribusiness climate and added value chain, providing for the widespread introduction of market principles in the purchase and sale of agricultural products, the development of a quality control infrastructure, the promotion of exports, and the production of high value-added agri-food products competitive in the target international markets.

3. The introduction of mechanisms to reduce the role of the government and increase the investment attractiveness of the industry, providing for an increase in the flow of private investment capital to modernize, diversify and support the stable growth of the agri-food sector.

4. Improving the system for ensuring the rational use of natural resources and environmental protection, providing for the rational use of land and water resources, forest resources.

5. The development of modern management systems, providing for the restructuring and further development of the structure of public administration in agriculture. 6. Increasing efficiency and phasing the redistribution of government spending by developing sectoral programs aimed at increasing labor productivity in farms, improving product quality, creating high added value.

7. Development of science, education, a system of information and consulting services, providing for the use of effective forms of disseminating knowledge and information integrated with production and research, educational and consulting services in agriculture.

8. Implementation of rural development programs, providing for the promotion of a balanced and stable rural development.

creation of a transparent system of industry statistics, providing for the implementation of reliable methods for collecting, analyzing and disseminating statistical data through the widespread use of modern information technologies.

Of course, great successes in agriculture are the result of thoughtful and consistent measures taken by the government, taking into account the peculiarities of our republic and rich experience, as well as world best practices. In this regard, the Strategy for Action in the five priority areas of the development of the Republic of Uzbekistan for 2017-2021 determined the country's path to the highest level of development. The action strategy determines the rational directions of modernization and accelerated development of agriculture, highlighting the vital issues that need to be addressed [2].

It is well known that in any society, economic reforms are carried out by economic levers. Among these levers, the practice of reforming the financial and credit system plays an important role. In this context, improving the financial sustainability of agriculture in accordance with the requirements of market relations is a key condition for effective financing of agricultural production.

Currently, the objective need for further improvement of the agricultural financing system of the republic is determined by the following factors:

1. Lack of working capital and collateral for obtaining loans by existing dekhkan and farm enterprises;

2. A high level of risk for existing dekhkan and farm enterprises producing agricultural products and, conversely, a low level of lending by commercial banks due to weak mandatory collateral;

3. Incomplete functioning in practice of the mechanism of farm leasing rights to land plots and obtaining a loan as a guarantee for future crops;

4. Based on requirements, attraction of international credit lines, the absence of private equity capital in the amount of $25 \%$ of the project in dekhkan and farm enterprises and others.

At the same time, the existing system of commercial banks crediting of business entities established in the country equates the peasant and dehkan farms engaged in the production of agricultural products with the same level of entrepreneurship as in other sectors. 
Citation: Temirkhanova Mo'tabar Juraevna (2019) Improving the the Financial Stability of Agriculture under Conditions of Modernization of the Economy. Journal of Media \& Management. SRC/JMM-103. DOI: doi.org/10.47363/JMM/2019(1)103

In other words, in small industrial enterprises the repayment of loans from commercial banks is short-term and they can pay interest rates. However, due to the seasonal nature of production in peasant and dehkan farms, the return on investment (income) for production is dependent on the year's end.

However, it is important to study such issues as livestock-breeding entrepreneurs with an income in 2-3 years period and ability to repay expenses, including bank loans or interest rates.

\section{Analysis of the literature on the subject}

One of the main factors for increasing the efficiency of resource use in the country's agriculture is the further improvement of the financing system for modernization and diversification of the industry. And also, taking into account the available resources, it is advisable to use the resources of the financing system targeted, purposefully and effectively. According to Sh. Allayorov, "in the context of modern globalization and international economic integration aimed at financing agriculture and ensuring its financial stability, improving the standard of living and well-being of the population, especially meeting their demand for food, is the highest priority [3]."

S. Elmirzaev states that the financing of subjects' activities can be financed by own and borrowed funds, which in turn are subdivided into internal and external sources of financing [4]. B. Sattarov also observed the practice of state budget financing in transition economies but the idea is that these funds will become their own capital [5]. E. Shodmonov substantiated that it is necessary to strengthen the practice of leasing financing in the conditions of the unstable financial situation of agricultural enterprises and limited access to sources of financing investments, it is advisable to introduce the sale of grain and cotton through futures contracts in excess of state orders.

\section{Analytical results}

Improving the economic efficiency of agricultural production in the country requires the rational organization of production at agricultural enterprises; the widespread use of advances in science and technology, new highly effective machines and equipment, agrotechnical and zootechnical methods, and new methods of labor and production organization. Assessment of agricultural enterprises is a criterion for the effectiveness of the national economy, in other words, it is based on the growth of labor productivity in society, and the growth of labor productivity is reflected in the growth of production and national income.

As a result of the implementation of laws and decrees of the Government on the growth of agricultural production in our country and the measures taken, the annual production volume increases from year to year (Table 1). In particular, if we look at the growth rates of grapes in our country in 2016-2017, in 2017 compared to 2016, the growth rate for all categories of farms was $100.8 \%$, of this, Fergana region increased by $122.6 \%$, Karakalpakstan - by $116.0 \%$, Andijan region - by 103.0\%, but Bukhara, Jizzakh, Kashkadarya, Namangan, Syrdarya, Tashkent and Khorezm regions produced slightly less agricultural products than the previous year. At the same time, as for farms, dehkan farms and agricultural organizations, the growth in the number of farms compared to the previous year has not been reported at the regional level. However, in most of the regions there is an increase compared to the previous year, if we look at the share of dehkan (private subsidiary) farms and organizations engaged in agricultural production.

Of course, increasing agricultural production and meeting the needs of our people for environmentally friendly products is one of the pressing problems, so, one of the main factors is the financial support of producers to increase agricultural production. In other words, it is possible to increase agricultural production through the use of modern technology. Therefore, it is no secret that commercial bank lending is one of the most important sources of financing their activities. There are several types of bank loans available for financing farms. In particular, for example the usual non-preferential commercial credit for working capital and production development, soft loans from the "preferential fund" of commercial banks, mortgage loan, start-up micro-credits, microcredits for the expansion of production, concessional loans to finance cotton and grain under government contracts. It is worth noting that at the meeting of the Cabinet of Ministers on December 21, 2015, Asaka Bank was tasked to develop viticulture, which is one of the most important parts of agriculture. 
Citation: Temirkhanova Mo'tabar Juraevna (2019) Improving the the Financial Stability of Agriculture under Conditions of Modernization of the Economy. Journal of Media \& Management. SRC/JMM-103. DOI: doi.org/10.47363/JMM/2019(1)103

In this regard, the JSCB "Asaka" is working to increase the share of the private sector in the production and service sector. In 2017 the Bank for the purpose of filling the domestic consumer market with domestic food products and a sustainable provision of the population's food needs was allocated 376 billion sums loans to support the companies of food industry.
Also for encouraging the expansion and diversification of competitive high-quality non-food consumer goods, further enrichment of the domestic consumer market, establishment of new local enterprises on production of ready non-food products and modernization, technical and technological re-equipment of existing ones in 2016 and 2017 there were issued loans on the

\begin{tabular}{|c|c|c|c|c|c|c|c|c|c|c|c|c|}
\hline & & & \multicolumn{10}{|c|}{ Including: } \\
\hline & \multicolumn{3}{|c|}{ Farms of all categories } & \multicolumn{3}{|l|}{ Farms } & \multicolumn{3}{|c|}{$\begin{array}{l}\text { Peasant (personal subsidiary) } \\
\text { farms }\end{array}$} & \multicolumn{3}{|c|}{$\begin{array}{l}\text { Organizations engaged in agri- } \\
\text { cultural activities }\end{array}$} \\
\hline & $2016 \mathrm{y}$ & 2017 y. & $\begin{array}{l}\text { Growth } \\
\text { rate, } \%\end{array}$ & $2016 \mathrm{y}$. & $2017 \mathrm{y}$. & $\begin{array}{l}\text { Growth } \\
\text { rate, } \%\end{array}$ & $2016 \mathrm{y}$ & $2017 \mathrm{y}$. & $\begin{array}{l}\text { Growth } \\
\text { rate, } \%\end{array}$ & 2016 y. & $2017 \mathrm{y}$ & $\begin{array}{l}\text { Growth } \\
\text { rate, } \%\end{array}$ \\
\hline $\begin{array}{l}\text { Republic of } \\
\text { Uzbekistan }\end{array}$ & 1735810 & 1748915 & 100,8 & 921449 & 862043 & 93,6 & 788803 & 861897 & 109,3 & 25558 & 24975 & 97,7 \\
\hline $\begin{array}{l}\text { The Re- } \\
\text { public of } \\
\text { Karakalpak- } \\
\text { stan }\end{array}$ & 6037 & 7002 & 116,0 & 586 & 883 & 150,7 & 5117 & 5781 & 113,0 & 334 & 338 & 101,2 \\
\hline \multicolumn{13}{|l|}{ R E G I O N S: } \\
\hline Andijan & 76705 & 78993 & 103,0 & 46532 & 40945 & 88,0 & 29879 & 37716 & 126,2 & 294 & 332 & 112,9 \\
\hline Bukhara & 194443 & 188967 & 97,2 & 83940 & 79969 & 95,3 & 109865 & 108545 & 98,8 & 638 & 453 & 71,0 \\
\hline Jizzakh & 32898 & 32399 & 98,5 & 17935 & 16120 & 89,9 & 14855 & 16165 & 108,8 & 108 & 114 & 105,6 \\
\hline Kashkadarya & 109357 & 106971 & 97,8 & 62451 & 58817 & 94,2 & 45324 & 46664 & 103,0 & 1582 & 1490 & 94,2 \\
\hline Navoi & 83736 & 85187 & 101,7 & 38593 & 38740 & 100,4 & 44508 & 46398 & 104,2 & 635 & 49 & 7,7 \\
\hline Namangan & 126933 & 119863 & 94,4 & 53216 & 48201 & 90,6 & 72472 & 70405 & 97,1 & 1245 & 1257 & 101,0 \\
\hline Samarkand & 607085 & 615496 & 101,4 & 396954 & 380361 & 95,8 & 205281 & 229450 & 111,8 & 4850 & 5685 & 117,2 \\
\hline $\begin{array}{l}\text { Surkhan- } \\
\text { darya }\end{array}$ & 135518 & 135890 & 100,3 & 78451 & 76446 & 97,4 & 56365 & 58762 & 104,3 & 702 & 682 & 97,2 \\
\hline $\begin{array}{l}\text { Syrdarya } \\
\text { river }\end{array}$ & 16215 & 14459 & 89,2 & 5816 & 2966 & 51,0 & 9607 & 10671 & 111,1 & 792 & 822 & 103,8 \\
\hline Tashkent & 174050 & 162258 & 93,2 & 102950 & 91210 & 88,6 & 59980 & 60228 & 100,4 & 11120 & 10820 & 97,3 \\
\hline Fergana & 127793 & 156638 & 122,6 & 19671 & 14324 & 72,8 & 105394 & 139551 & 132,4 & 2728 & 2763 & 101,3 \\
\hline Khorezm & 45040 & 44792 & 99,4 & 14354 & 13061 & 91,0 & 30156 & 31561 & 104,7 & 530 & 170 & 32,1 \\
\hline
\end{tabular}

Table 1: Indicators of grape production in the country for 2016-2017 Data.

In order to develop viticulture, one of the main agricultural sectors, the Bank has developed a set of credit conditions that provide comprehensive support to businesses operating in the sector, including loans were issued, for 7 years with 3 year grace period for construction of new vineyards and reconstruction of unsuitable ones, for a period of up to 2 years with a grace period of 9 months in the organization of grape growing and planting vegetables, melons and legumes among the grapes (for purchase of seeds, seedlings, fuel lubricants, mineral and local fertilizers, chemicals), for up to 1.5 years with a grace period of 6 months for repayment of working capital for the purchase of grapes grown by agricultural enterprises for agricultural firms, for up to 
Citation: Temirkhanova Mo'tabar Juraevna (2019) Improving the the Financial Stability of Agriculture under Conditions of Modernization of the Economy. Journal of Media \& Management. SRC/JMM-103. DOI: doi.org/10.47363/JMM/2019(1)103

amount of 305.6 billion sums and 365.0 billion sums respectively.

5 years with a grace period of 2 years for long-term loans for viticulture (procurement of specialized machinery and technologies).

To date, 42 viticulture agro-firms have been established in the regions to improve the efficiency of the vineyards in the country. "Asaka" Bank has financed 648 projects 169.1 billion soums for the past years. As a result of these projects about 40 agricultural machineries were purchased, freezers with a capacity of 19 thousand tons were created, about 2000 hectares of new vineyards were planted, and about 900 hectares of old vineyards were reconstructed.

Accounts of agro-firms and more than 10,000 farms which specializing in viticulture were opened in Asaka Bank branches. In order to create them comfortable conditions nowaday 42 mini-banks of "Asaka" bank are operating in the districts of our republic.

In 2019 , the country plans to produce 1.9 million tons of grapes and 8.0 thousand hectares of new vineyards will be planted. The total amount of these projects is 75.1 billion sums (of which the bank credit is 20.1 billion sums). 2.2 thousand hectares of vineyards will be reconstructed. The project cost is US $\$ 6.2$ billion. sum (including bank credit - 635,0 million UZS). Under these projects, more than 900 new jobs will be created in the regions of the country.

The number of projects on development of viticulture in the regions of the country, financed by Asaka Bank, in 2017 has slightly decreased, totaling 210 projects, and in terms of provinces, the share of Samarkand region, Jizzakh region and Ferghana region is slightly higher than in other regions. The table below shows the distribution of projects financed by Asaka Bank by region

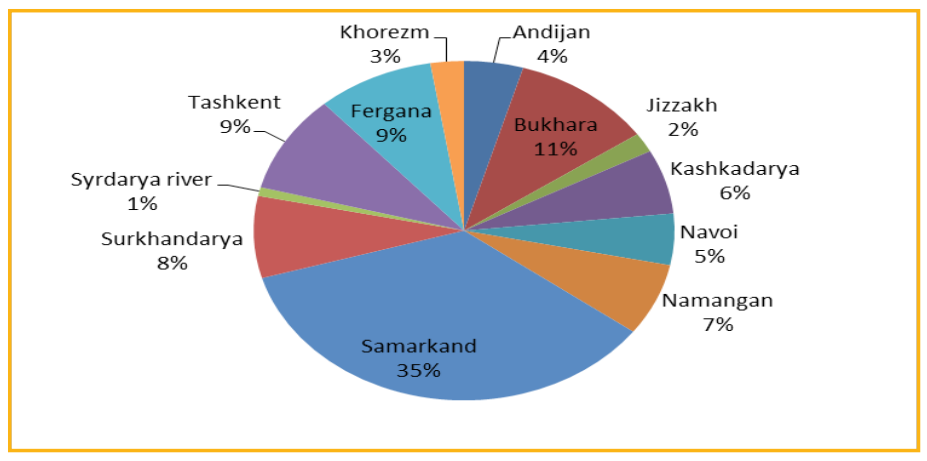

Figure 1: Projects financed by Asaka Bank for the devel- opment of viticulture by region (2017). In agriculture, in recent years, the enterprises in the formation of their financial resources in addition to its own funds pays special attention to the funds of commercial banks, extra-budgetary funds and to financial institutions, such as credit unions, as well as, centralized state financing in public financing. Also increasing of banks' capital and attracted deposits from clients allows further expansion of banks' participation in structural transformation, modernization, implementation of promising and highly effective investment projects, expansion of production and financial support of consumer goods in the basic sectors of the economy.

\section{Conclusions and Suggestions}

Production of agricultural products in the agricultural sector of the country by working in harmony with national traditions, creation of unique competitive products, reporting on the natural location of territories, exporting them at the level of products that are in great demand both in the domestic and foreign markets. It is an important factor in completing such tasks as production in the conditions of specialization of various agricultural products, including those with owners (farmers and dekhkan farms), interrelated processes between manufacturers of products and the companies that process, sell and service in various ways, highly innovative businesses providing agricultural services, willingness to cooperate and compete with networked enterprises, formation of legal and regulatory framework in line with market principles of agricultural regulation, comprehensive service infrastructure and availability of highly qualified specialists [6-11].

Of course, to achieve this, the following must be taken into account for the sustainable development of agriculture on the basis of financial sustainability and organization on an innovative basis:

1. To study the best practices of foreign countries on sustainable and innovative development of agriculture in our country;

2.To systematize the factors affecting the development of the agricultural sector on the basis of financial sustainability, and to study their impact and specifics of the industry;

3. To develop susutainability in the agricultural sector in the conditions of economic modernization, to devel- 
4. On the basis of stabilization financial support to identify the new opportunities for financial support of the agricultural sector and to attract the foreign investors on the basis of financial sustainability;

5. To improve the economic condition of producers which operate in the regions with difficult conditions for the creation of agricultural products and the ways of state promotion in further development of agricultural markets of the country;

6 . To solve problems waiting for a solution through fruit and grape growing and by improving the organizational and economic mechanisms of ensuring the sustainability of infrastructure components;

7. To determine the ways of sustainable development of the activities of specialized farms and dehkan farms in the country through cooperative forms and relationships;

8. To determine the directions for ensuring integrated development of agricultural production in the country.

\section{References}

1. Decree of the President of the Republic of Uzbekistan (2019) "On Approval of the Agriculture Development Strategy of the Republic of Uzbekistan for 2020-2030".

2. Decree of the President of the Republic of Uzbekistan on the strategy of further development of the Republic of Uzbekistan (2017) People's Word newspaper No. 28 (6722).

3. Allayorov Sh (2017) Innovative conceptual aspects of improving the system of financing of agriculture and water resources. International Finance and Accounting. Tashkent 10: 118.

4. Elmirzaev S (2015) Corporate finance. Tutorial. T "Industrial Standard 65P.

5. Sattorov BK (2017) Some issues of financial resources formation in joint-stock companies. Economics and Education. Tashkent 1: 112.

6. www.asakabank.uz-Website of the Bank «Asaka».

7. Temirkhanova M Zh (2017) Ways to improve the accounting for liabilities in the travel agency European Journal of Economics and management Sciences 2:3-6. 8. Temirkhanova M Zh (2016) Regulatory framework for the organization of financial accounting and reporting in tourist organizations of the Republic of Uzbekistan Herald of science and education 3:18.

9. Mekhmonov S ( 2014) Reforming the public sector accounting in Uzbekistan. The 8th Conference of Cul-

J Media Managem, 2019 ture \& Accounting Association (China) 169-173. 10. Mekhmonov S (2018) The main directions of the accounting reforms in the state sector in Uzbekistan. International journal of research in social sciences 8: 217-223.

11. Temirkhanova M Zh (2016) Analysis of financial results tourism organization. International Scientific and Practical Conference World science 9: 16-19.
Copyright: (92019 Mo'tabar Juraevna T. This is an open-access article distributed under the terms of the Creative Commons Attribution License, which permits unrestricted use, distribution, and reproduction in any medium, provided the original author and source are credited. 